\title{
EDUCATION AND LITERATURE IN THE HILL AREAS OF MANIPUR DURING THE BRITISH RULE
}

\section{DR SHEIKHOHAO KIPGEN*}

Associate Professor in the Department of History, Manipur College

\begin{abstract}
The arrival of William Pettigrew is synonymous with the arrival of modern education among the tribal people of Manipur. The British administration served as a facilitator in this process. It is an open secret that neither the Manipur Maharajas nor the tribal chieftains who had practiced a system of governance in the hills of Manipur could affect the changes that have occurred within a span of a century that is ever since the British colonialist and its missionaries set foot on the soil of Manipur. If the tribal people have reached a semblance of development, a sizeable portion of credit should go to the untiring works of the western, native and the western missionaries who have slogged in their own measure to take the tribal people to the heights of progress and advancement.

The expansion of British colonial administration brought changes of unprecedented nature among the hill people. Historically, the tribal people were never within an integrated political structure or a unified administrative network of the kings of Manipur. It was only when the British consolidated their foothold in the valley and consequently incorporated the administration of the hill areas under them; tribal people were introduced to western education. The establishment of churches and educational institutions initiated the process of epoch making changes among the tribal society. It is to note here that in spite of the widespread character of Bengali script in the valley, acquisition of the knowledge of reading and writing among the tribal did take place only with the advent of education brought by the Christian missionaries. The missionaries proved to be a boon for the tribal literature. During the British period several local writers came up in small measures and many works were accredited to them which were mainly the secular or gospel publications. This has led to the growth and development of their respective tribal literature in the years and decades later and continues till today.
\end{abstract}

KEYWORDS: Education, Christianity, literature, dialect, etc.

Received: Feb 23, 2021; Accepted: Mar 13, 2021; Published: Mar 20, 2021; Paper Id.: IJHRJUN20211

\section{INTRODUCTION}

Education plays a vital role in the life of the individual human being and society. It set the light of knowledge by exploring the myth and removing the dark veil of ignorance from the human minds. Education plays the most effective instrument for bringing about positive changes in the society. As education sharpens one's intellect, it also expands and widens one's mental moral and spiritual horizons. A part from the role of developing and molding the individual, education has to inculcate the spirit of tolerance, accommodation, fraternity, harmony and peace. It is the prime mover and agency for social transformation.

While speaking education of the tribal people in Manipur the tribal community is highly indebted to this great humanist and missionary of the century - William Pettigrew, who is also known as the 'father of education'. His name is indelibly inked from the pages of history in as far as the history of the arrival of modern education especially among the tribal people of Manipur is concerned. In fact the earliest groups of educated tribal people 
were also the earliest converts who studied in the school run by the missionaries. Pettigrew had a broad vision. He was instrumental in bringing the various hill tribes together and his contribution towards the integration of the people of Manipur remained unparalleled. Pettigrew and the Christian Missionary contribution to western education in Manipur in general and particularly among the hill people is remarkable. Manipur owes a life time gratitude to this 'One Man Army'. A report about Christian education in Manipur during the year 1913 throws light on this which is reproduced as follows:

Four or more Kuki boys are now in the school, and it is hoped that in the next three years, or probably before, they will be ready to act as teachers and preachers for this great and promising tribe. For some years there has been a hostel for Kuki boys at Imphal, who attend the school under Mr. Pettigrew's care for the purpose of studying Manipuri. There are at present about twenty of these boys in the school and hostel, and it is understood that there would be no objection to a missionary to the Kukis taking charge of this hostel and superintending the moral and spiritual needs of the boys. ${ }^{2}$

The educational work of the entire state of Manipur is conducted under the supervision of Rev. Pettigrew who is stationed at Ukhrul. Though the school is mainly intended for the Tangkhul Nagas, several Kuki boys who could afford to study have also greatly benefitted and subsequently became the government servants. Pu Teba, Pu Longkhobel, and Pu Sheifalut(Sheijalet), who were schooled in the Ukhrul School, became Head Clerk in the sub-divisional office at Ukhrul, second clerk in the sub- divisional office of the South West area, and a teacher at the new secondary school at Kangpokpi respectively. Pu Ngulhao who was trained and taught at Kohima Middle English School and at the Higher School at Jorhat also visited Ukhrul and helped Pettigrew in educational work. The trained pastors and evangelists passed on their knowledge to the churches which resulted in the formation of Sunday schools among the churches. ${ }^{3}$ A decade later, Rev. Watkin R. Roberts from Aizawl in Mizoram, who was an independent missionary arrived Churachandpur district in 1910 and began his work at Senvon village with the permission of the chief. His mission was named as Thadou-Kuki Pioneer Mission, which is now known as Evangelical Congregational Church of India (ECCI). The arrival of the Christian missionaries and the subsequent establishment of churches, schools initiated a process of epoch making changes which have been microscopically analysed and studied by the scholars the world over.

\section{Progress of Educational Development}

Education became one of the greatest agents of social change and transformation. It gave them a new lease of life. Introduction of modern education and for its language became an integrating force for all the tribal Christians as it bridge the gap of pre-literate tribal societies. The Gospel of Jesus Christ coupled with the spread of western education brought tremendous social revolution and transformation to such an extent that there is so much of change in our living standard, outlook, mindset, way of life, and all other aspects of socio-economic life. Young tribal Christians are now no longer behind others in as far as educational competitions and degrees are concerned. It may be noted here that the largest chunk of Chin-Kuki-Mizo people inhabited the district of Churachandpur where most of the well-to-do families resided in the Churachandpur town and its adjoining areas. What Rev. Dr. I Benwati have said in this regard is noteworthy: "With so many tribes and sub-tribes Churachandpur was an enterprising and competitive town. What amazed me was that Churachandpur has produced more IAS officers, more theologian, Christian leaders, evangelists, missionaries and business people than any other place in Northeast India, and perhaps in the whole of India, when considered from a small town of this size. Some sociologist or social analyst can make a thorough study of this phenomenon and get a doctorate from the Manipur University or Northeastern Hill University. In the ancient past the greatest mind in all history seemed to have 
been concentrate in Athens in Greece at one period, and to me Churachandpur is one such place." ${ }^{4}$ Truly the district has reason to be proud of as it is reported to be one of the top ranking districts in the country in term of pass percentage in all India Civil services Examination. Great Indeed!

It is to note that the tribal of Manipur are generally simple, straightforward, honest, brave, reliable, generous, friendly, humorous, self reliant, free, hardworking, and adventurous. As highlanders they were fierce and fearless when provoked wrongly though they are peaceful and peace-loving in nature. Their main occupation in the past was jhumming or shifting cultivation, fishing, hunting, etc. and as such they lived in small groups, isolated and far-off from one another. As no human society exists and grows without education of some kind, the tribals too have their own traditional way of education even before the art of reading and writing was known. Each and every individual acquire some sort of education, even if she or he has never spent a day in a formal schooling, because all his acquired characteristic are the product of experiences and activities which are dedicational in nature. Their education thus includes all influences and activities in life by active participation. Therefore, it would be naive to believe that there were no educational activities in the tribal society of Manipur prior to the establishment of modern day educational institute in the tribal areas.

For a considerable length of time the tribal people of Manipur remained unaffected by the progress of modernization. In the very beginning the conservative Kuki chiefs rejects Christianity and western education. They simply gave importance and took pride in performing the 'Feast of Merit' ${ }^{5}$ like 'SA-AI'(hunter's ritual) - a ceremony for killing a large number of animals in wild games, CHANG-AI (paddy ritual)- a ceremony for a bountiful harvest and GAAL-AI (Great warrior's ritual) - a ceremony related to performing with the heads of enemy as trophy of prowess. The performance of SA-AI by a great hunter involved killing of a Mithun and holding of a grand feast associated with the erection of memorial pillars or a stone monolith. ${ }^{6}$ Ignorance, superstition, isolation and living a life of constant warfare often leading to destruction of life and property was what it characterize the tribals in the pre-Christian dispensation.

With the entry of missionaries among the tribal area the scene had began to change. It brought upon the socioeconomic and socio-educational transformation and injected a new spirit into the life of the Kukis which was never known before. The art of reading and writing which is generally termed as 'Education' or 'Literacy' was introduced in the tribal areas by the western missionaries. Thus, the pioneering effort to develop the tribals of Manipur had started with the introduction of education and health services as part of their missionary activities in the interior part of the hill areas in the state. However, due to numerous problems like ignorance, poverty, poor communication system, traditional belief and rituals, etc., the important tool of modernization or civilization could not spread fast and it took many decades in the first half of the $20^{\text {th }}$ century to produce a $1 \%$ literacy population among the tribals ${ }^{7}$. The following ten points (10) points ${ }^{8}$ are listed out as the major impact of western education among the tribes.

- It contributes towards their social reconstruction and broadened their outlook.

- It makes their participation effective in the developmental process of the state and their society.

- It creates flexibility of the minds to accept new ideas, to experiment and improve.

- It helps to develop the overall socio-economic condition of the tribal society by providing employment opportunities, improving communication, marketing facilities, etc.

- In helps in upgrading the standard of living of the tribal people as education and development are interrelated. 
- It makes them conscious of their political rights and duties in the society and produces social and political leaders among them.

- It helps them to be self sufficient, self reliant and better equipped in the battle of life to become an economic asset not only to the family but also to the society as well.

- It makes them more knowledgeable and develops their ability in critical thinking, love for innovation and accept the changes that are taking place in everyday life.

- The introduction of western education imparts literary which is necessary for the growth of social and political democracy.

- It also helps them to preserve their traditional values through folksongs, folktales, folkdances and so on and so forth.

\section{Literary growth and Development}

The influence of Christianity worldwide on art, music and literature is enormous. In the same way one of the greatest impacts of Christianity and modern education among the tribal society is the growth and development of its literature. In Manipur among the tribals the Thadou-Kuki is the most widely spoken dialect of all the tribal dialects. It is only next to Manipuri locally known as Meiteilon. The diachronic linguistic studies of the tribals such as Thadou-Kuki, Tangkhul, Mao, and other cognate languages and dialects such as Mizo, Tiddim-Chin, Hmar, Vaiphei, Mara, Paite, Simte, Kom, Gangte, Zou, Kabui, Liangmei, etc. revealed that they had no literature of their own. The present alphabet of the Naga and KukiChin groups are derived from the Roman script. However, according to the tradition of the Kuki-Chin group they were said to have possess their own script written on parchments. It remains only as a legend.

The advent of Christian missionaries coincides with the education of the Nagas and the Kuki-Chin groups of Manipur. Thus, in the context of historical linguistics of the Thadou-Kukis and their cognate tribal dialects, the beginning of written languages can be traced to the arrival of the western Christian missionaries. The Christian contribution to development of languages in the Northeast goes as far back as 1830s. Christianity is largely responsible for providing a script to many oral tribal languages and for the creation of essential linguistic infrastructures such as grammars, dictionaries and basic literature for the development of local languages. Even the major languages of the region such as Assamese were salvaged from extinction by Christian missionaries. In this effort to preserve and promote indigenous cultures, Christian missionaries have promoted the preservation of cultural artifacts, establishments of museums along scientific lines in different parts of the region.

The expansion of British colonial administration brought changes of unprecedented nature among the tribal people. Historically, the Kukis or for that matter the tribal people were never within an integrated political structure or a unified administrative network of the kings of Manipur. It was only when the British consolidated their foothold in the valley and consequently brought the administration of the hill areas, they were introduced to western education. The establishment of church and educational institution initiated the process of epoch making changes. In spite of the widespread character of Bengali script in the valley, acquisition of the knowledge of reading and writing among the tribal people did take place only with the advent of education brought by the Christian missionaries. The missionaries proved to be a boon for the tribal literature. They were reduced to writing in Roman script. Rev. William Pettigrew introduced the Roman script among the Tangkhuls, Dr. G.G. Crozier among the Thadou-Kuki, and Rev. W. R. Roberts among the 
Vaipheis in 1917. The latter with the help of Pastor Thangkai published the gospel of St. John in Vaiphei. In 1926, the Tangkhul Testament was published through the effort of Rev. W. Pettigrew. ${ }^{9}$ Today almost all the different communities living the hill and valley have their Holy Bible in their own dialects and languages and the complete Holy Bible minus Apocrypha.

The Thadou-Kuki language is widely spoken to the people belonging to the anthropologically Kuki-Chin-Mizo sub group of Tibeto-Burman sub-family of Sino-Tibetan families of languages. It shares linguistic and ethnographic similarities with the other dialects of the Kuki-Chin sub-groups. Therefore, it is to assert without any fear of contradiction that Thadou pao or Thadou-Kuki language is a living and vibrant language. Now the Thadou-Kuki language is taken as Modern Indian Language (MIL) from Class IX, X, XII and up to the degree level in the state of Manipur. It, therefore, goes without saying that Thadou-Kuki speaking students are the largest in number from the lowest level to the University level. Take for instance, the number of students who opted Tangkhul or Paite or Hmar as MIL in the Council of Higher Secondary School Examination (COHSEM), Manipur hardly comes up to 300-450, while in the case of Thadou-Kuki there are more than 2000 (two thousand) candidates in the said examination opting Thadou-Kuki as MIL. ${ }^{10}$

Gleaning historical records, the British India Government accorded recognition to Thadou-Kuki language as the official language for the purpose of Administration in Manipur similar to Meitei-lon and awarded 'special allowance' to British officers who acquired the working knowledge in what is called 'Thadou pao'. This facility was extended to Somra Tracts of Myanmar, known as then 'Unadministered Areas', mainly due to the large number of Thadou-Kuki speaking people living therein. Besides, at one point of time in history due to the widespread character and the use of the language by a large number of people in the hills of Manipur it was also called 'Sorkar pao' which means the language of the Government. Official records are witnesses to this fact without pretending to speak with exaggeration. In his letter addressed to the Deputy Inspector General of Military Police - Burma, dated 11th Jan. 1919, J.C Higgins ICS, Political Officer stated that -

“....Thado (Thadou) Kuki is the language of the Kuki tribes in general and is intelligible to all the Kukis in the Somra area and Thaungdut State, thought the various tribes speak it with some slight variations....The learning of the Tangkhul dialect spoken in the Somra will present very considerably difficulty, as it is an entirely unknown language... The dialects throughout the Tangkhul country vary to a surprising extent even from village to village."

“... Tangkhul dialects are not on the list of languages for which a reward is offered by the Assam Government, as no officer has ever learnt them. They are quite distinct from both Manipuri and Thado. Manipuri and Thado contain certain roots in common, but are quite distinct languages and knowledge of one does not enable a person to make him understood by persons speaking the other. The Assam Government grants a separate reward to officers passing in both..." 11

This shows that Thadou-Kuki language is the lingua-franca of all the erstwhile Kuki tribes and till today it is so to some extent. This people have no difficulty in communicating one another even by using their own dialects. But it is not the same in the case of Tangkhuls who speak different dialects to an amazing extent of variation from village to village. Their dialects are not intelligible to each other.

Christianity has a far reaching consequence upon the socio-cultural, economic and political life of the tribal people. The impact is great. It took a fairly long time to come to North East India, but it took unassailable lead to change 
the region for the better. The growth and development of literature among the tribal society beginning from the $20^{\text {th }}$ century is one of the greatest impacts of Christianity. With the switch-over from traditional religious beliefs to Christianity the outlook of the people had also began to change. For the tribal people to forsake the age-old practice of heathenism and turn to the living God is something novel and wonderful experience. They were conservative in their belief and were as superstitious as the bigoted Hindus of the valley. As such there many instances of falling back to heathenism which was heart rending for the missionaries. But once the Gospel of Jesus was accepted wholeheartedly, gloomy thoughts disappeared and it brightens the lives of the tribal people. This changed outlook and attitude in its turn produced enormous literary publications. The lives of the tribal people have undergone many changes hereafter. The new religion has done so much for the shaping of the tribal social structure. It took them to greater heights with their service and dedication.

Since Ukhrul became the first Mission centre or station of William Pettigrew, the Tangkhuls had the advantage of being ahead in many respects especially in literature when compared to their tribal counterparts. The establishment of mission schools, churches and the running of Sunday schools is a case in point. Pettigrew introduced the Roman script and translated initially the scriptures of the Gospel of Mathew and the Epistle to the Romans in Tangkhul dialect. The former is printed and sufficient copies were also made ready for the study of the Intermediate Bible lessons for the year 1910. The Gospel of Mark and the Epistle to the Corinthians were also kept ready for distribution to the people in 1911. Even the second edition of six Tangkhul Naga school textbooks has been issued at the expense of the state. Then, in 1918 Rev. William Pettigrew had made great achievement in terms of literary work when his book on Tangkhul Naga Grammar and Dictionary got published. In 1927 the whole chapter of New Testament translated in Tangkhul dialect and other hymnbooks, primers arithmetic readers for higher class prepared by himself got published. ${ }^{12}$ It was only in the late $1960 \mathrm{~s}$ the complete Holy Bible in Tangkhul was published after translating the scripture by R. Ningatei. Revisions were made several times later and many wordings were changed in the very recent publication of the Tangkhul Naga Bible. In spite of all this, Rev. William Pettigrew has the credit of laying the foundation of Tangkhul Naga literature. He left indelible footprints especially in the field of literature for the Tangkhuls in particular and for the tribals in general.

Today all the different tribal communities can read and write in their own dialect using the Roman alphabet. During the British rule in Manipur, only few literates voluntarily imparted education even among the adults by way of running night schools at their own expense and accommodation in their own house after the normal and usual day's work. People began learning the basics of reading and writing. It was a new experience which they never felt before. When the translated Bible scriptures were printed out people can read and understand easily in their own mother tongue. The impact was great. Thus, there was a tremendous change in the tribal's world view. Further, it is pertinent to note that the missionaries' event learnt the local dialect and devised the first grammar books. They introduce western music and prepared song books for the use of church service, gospel related gathering and other social function and programmes. The simple tribal people did not find it difficult to adjust and mould themselves to this new environment and situation. It also appears that they did not suffer from this transition syndrome. Christianity and English education thus proved to be a boon for the tribal literature.

The Christian missionaries who came to our region had given us the most valuable messages - the Gospel of love and forgiveness. The impact was so great that today $9 / 10$ of the total area of Manipur became Christian dominated area. Today the Christians of different denominations read, understand and receive the word of God in their respective dialects and languages, which they can easily understand. The beginning of tribal dialects and languages in written form is 
therefore traced to the arrival of western missionaries. The seeds they planted and watered down by our own people precisely the earlier converts bore fruits and today almost all the tribal people enjoy the taste. There is no denying of the fact that the missionaries in Manipur like Pettigrew, Crosier and Watkin Roberts were the first to bring welfare programmes. The missionaries set an example of social service with high spirit of enthusiasm, which was later followed by other. With the establishment of schools and Churches, the Kukis and Nagas began to receive formal education. It was a novel thing which they had never experienced before. With further qualifications in different fields, few tribals got white collared jobs and receive salaries. Their outlook became different. Being egalitarian in nature Christianity respected every one as equals in dignity, honour, and prestige. Thus, Christianity had brought a sea change and created tremendous impact on the socio-economic life of the tribals.

Introduction of western education undoubtedly stands as the pillars of changes. The translation of scriptures in the respective dialects of the tribal communities has laid down the basis of literature. Followings are some of the points that is to be put in the nutshell,

- 'Heathenism' was forsaken and the true living God began to be worship;

- With the establishments of schools, the art of writing and reading eventually began to be practiced;

- Progress in literature could be seen in the form of publishing school text books written by the early educated converts, of course, with the assistance of the missionaries;

- As education progress and thrive into the tribal society it enables them to enjoy the taste of having effective communication among themselves. People began to involve in literary works. They would also write letters and sent to their distant relatives. Inter and intra-tribal communication as a whole took a new beginning.

- Education has brought enlightenment and empowerment. It created white-collar jobs, which enabled the tribal to articulate their fears and made demands on successive governments both of the state and the country for their well-being. Christianity has raised the tribal people to the level of international standard in certain respects.

With the advent of Christianity and the spread of education today a number of books on tribal people have been written by themselves in their own dialects. Their study makes important contribution to the understanding of different aspects of the socio-cultural life afresh. These books contain deeper anthropological insights and the socio-cultural changes as a result of the impact of western culture through the activities of governmental administrative machineries and the Christian missions. The socio-cultural and historical study made by the local scholars contains more of authentic facts which have been hitherto unexplored. They sometimes understand their own history and culture better and deeper than outsiders though there writings are not free from subjectivity.

Though little progress has been made it had far reaching consequences in terms of modernizing the languages. The efforts of the early few converts who received modern education have contributed for the growth and development of the education and literature which could be evidenced from the fact that some amount local dialects have been codified. Local writers began to involve in writing grammar and other socio-educational books in small measure. This has led to the process of standardizing and modernizing the languages as well. 


\section{Early Local Writers and their Works - a Case of Thadou}

They can be broadly divided into two - secular and gospel publications. During the colonial period itself several local Christian writers flourished. Many of the secular and gospel publications were accredited to them. The composition and translation of the Hymn in 'Houbung La' (Church Hymn) based on the principles of Christian faith greatly contributed to the growth and development of contemporary Thadou-Kuki literature. Imminent religious converts of the time such as Pu Ngulhao Thomsong, Pu Seilet Singson, Pu Longkhobel Kilong, Pu Helkhup Chongloi, Pu Pakho Sitlhou, Pu Teba Kilong $\mathrm{Pu}$ Lunneh, $\mathrm{Pu}$ Palal and $\mathrm{Pu}$ Thangkhai were pioneers and pathfinders in this field. The role played by the missionaries and the local hymnologists in translating the hymns has its own unique importance in the field of Christian literature.

The Thadou Kuki textbook writers were evolving a literature for the various school subjects.

- In $1924 \mathrm{Pu}$ Longkhobel Kilong had written and published 'Thadou Lekhabul'. This became the first textbook used by the Kuki School going students.

- In 1926 Pu Teba Kilong had written Thadou-Anisuba'

- In 1927 Pu Ngulhao brought out Thadou Kuki First Primer called Lekhabul. It became a common textbook of all communities belonging to the Chin-Kuki-Mizo tribes.

- In $1938 \mathrm{Pu}$ Teba Kilong had written and published the 'Kuki First Primer' and 'Kuki Second Primer'. These educational textbooks of the early local writers formed the basis of the beginning of Thadou-Kuki literature. ${ }^{13}$

With regard to Pu Ngulhao his earlier works formed the basis of the growth and development of Thadou-Kuki style of writing was perhaps unparalleled in the history of Thadou-Kuki literature. Literature during the first three decade of the $20^{\text {th }}$ century was mostly Christian devotional hymns, translation of some of the books of gospel and other books of New Testament. His earlier Christian theological works in vernacular literature include-

- $\quad$ Pathen La-1922; (which means Gospel songs)

- $\quad$ Thukidong le Kidonbut-1924; (which means Query and response)

- $\quad$ Pathen Thu-1925; (which means Gospel Message)

- John Sut Kipana Thupha; (translated version of the gospel of St. John)

- Lung Phatvet-1930 (literally Lung means mind, and Phatvet means mirror)

- Rom mite Henga Paul Lekhathot-1933 ${ }^{14}$. (Paul's epistle to the Romans)

Ngulhao Thomsong and Dr Grozier translation of the New Testament was a great contribution and a unique mile stone achievement. It is an important landmark in the history Thadou-Kuki literature. The common people were exposed to the knowledge of the Bible and in the larger context to the outside world. Thus, Thadou-Kuki literature began its long journey from then onwards. This is one of the greatest contributions of Christianity and western education to the Kuki society.

In the context of Thadou-Kuki literature, Ngulhao Thomsong style of writing is reflected in the translation of scriptures especially the New Testament. His style of writings exerted influence so much so that till today, writers in the same dialect generally adopted this sort of traditional writing system though some have pointed out the defects. The 
Thadou-Kuki spelling system practiced currently by the majority writers is a system, which they derived from what is called 'Bible spelling' or 'Ngulhao spelling'. Till today the spelling system practiced by the people were taken from the system originally adopted by Ngulhao in his 'Lekhabul'.

They literary works of the locals can be broadly divided into two - Secular or Gospel Publications and the socioeducational textbooks. During the British period many local writers flourished and many works were accredited to them which were mainly the secular or gospel publications. These secular works or gospel publications totally outnumbered educational books (books written and meant for school students). In the context of Thadou-Kuki literature the contribution of Ngulhao is historically indelible as it characterized his unmatched contribution in this aspect.

Besides, the early hymnologist and lyricists had cut the first stones for the edifice in conquering printing socioeducational text books and gospel literatures in Thadou-Kuki dialect. The role played by the missionaries and the local hymnologists in translating the hymns has its own unique importance in the field of literature. They made a stupendous victory in mastering the language especially in setting down the right literary technique. Whatever may be introduction of western education undoubtedly stands as the pillars of changes. The translation of scriptures in tribal dialect has laid down the basis of their literature. Despite many inconsistencies and loopholes at present in the writing style, the tribal literature is moving ahead towards perfection. The tribal community is highly indebted to western missionaries for their yeoman service to them. This has led to the growth and development of their respective literature in the post independent period.

\section{CONCLUDING REMARKS}

Christianity has far reaching consequences upon the socio-cultural, economic and political life of the tribal people. The impact is great. It took a fairly long time to come to North East India, but it took unassailable lead to change the region for the better. The growth and development of literature among the tribal society beginning from the $20^{\text {th }}$ century is one of the greatest impacts of Christianity. With the switch-over from traditional religious beliefs to Christianity the outlook of the people had also began to change. For the tribal people to forsake the age-old practice of heathenism and turn to the living God is something novel and wonderful experience. They were conservative in their belief and were as superstitious as the bigoted Hindus of the valley. As such there were many instances of falling back to heathenism which was heart rending for the missionaries. But once the Gospel of Jesus was accepted wholeheartedly, gloomy thoughts disappeared and it brightens the lives of the tribal people. This changed outlook and attitude in its turn produced enormous literary publications and social progress. The lives of the tribal people have undergone many changes hereafter. It is to say that literature can do many things within a short span of time what politicians cannot do in a century or more. The tribal existing literature needs to be re-written on the line of the new generation. A comparative study of what is written today and what was written in the past few decades should be made. Human life at present and in the past provides many materials which should be translated into words. The tribal literature should ensure or prove their identity, history and culture. In order to trace ones' originality one need to go to the past by way of folktales, folksongs, myths, legends, etc. The life of the tribal people dramatically witnesses unceasing change even after the departure of their British masters. The advent of modern education among the tribal population and subsequent conversion to Christianity is largely responsible. On the colonial foundation, the emerging tribal educated middle class plays a new identity politics beyond the ethnic identity. The result of colonization manifested with the significant changes in the field of religious faith, socio-economy, education, literature and progress in many respects. It acted as a powerful force of social changes in the colonial and the contemporary times. 


\section{REFERENCES}

1. Access on internet on the topic Impact of Christianity - The Arrival of Western Education and Christianity in Manipur, Courtesy: IAP MHA CTL (The Internet Association for the Promotion of Manipur History, Art, Culture, Tradition and Literature), the Manipur page. On 23-09-2011.

2. Elungkiebe Zeliang 2005: History of Christianity in Manipur, Source Materials, published by Christian Literature Centre, Guwahati, p.37

3. The contribution of Christianity to the Kukis, written by Onkhothang Haokip Sunday, 29march, 2009. Access on internet, http://www.kukiforum.com Kuki people/religion on 04/09/2020.

4. Cited from an article on Christianity in Manipur by Rev. Lalrosiem Songate, access on internet on 24/09/2011 also referred, "How Christianity came to Manipur' written by Prof. Ladena through internet.

5. Cited from the Impact of Christianity among the Thadous, written by T.K. Siema, vice-President, TBA in a Souvenir published on the occasion of the Third General Conference at TBA mission centre Motbung, edited by Ricky V. Guite, 1992, p.9. SA-AI, CHANG-AI, \& GAAL-AI is a popular Thadou-Kuki term.

6. Sheikohao Kipgen, 2015; Political and Economic History of the Kukis of Manipur, published by Akansha Publishing House, New Delhi, p.86.

7. Cited from the paper presented by Dr Caroline Kim Guite, Assistant Professor, Deptt. of Education, Manipur University on the topic "The spread of modern education and its impact on the tribal society of Manipur" during the two day state level seminar on the theme "Social Change in tribal Manipur" during Marh 29-30, 1996, organized by Manipur University Tribal Students' Union, (MUTSU), p.2 Ibid; pp. 15-16.

8. Lokendra, M. (2014). Education and society in Manipur.

9. $\quad$ Prim Suantak Vaiphei, Church among the Hill Tribes in Manipur, Imphal, 1986, p.147.

10. I, myself being the member of the Thadou-Kuki Literature Society(TKLS), Manipur and secretary of the Text Book Committee for BA MIL, and Head Examiner of Thadou-Kuki subject MIL for the last thirteen years under the Council of Higher Secondary Education, Manipur had been well informed about the matter.

11. Extract from the letter No. Kmp/37/198/Dated the 11th Jan. 1919, From J.C. Higgins I.C.S. Political Officer Kuki Punitive Measures to the Deputy Inspector - General of Military Police - Burma.

12. Rev. Jonah M. Solo \& Rev. K. Mahangthei's compilation-Forty Years Mission in Manipur - Mission Reports of Rev. William Pettigrew; 2006, published by CLC, Imphal, p. 93.

13. Sheikhohao Kipgen; Thadou-Kuki Literature Khantou Machal ( A brief history of Thadou-Kuki Literature), 2010, published by Thadou-Kuki Literature Society (TKLS), Manipur, for BA MIL subject under Manipur University, Imphal, pp.8-9. Also cited from Rev. Vumthang Sithou's Thadou Kuki Christiante Thusim Chomcha 1908-2008, published by - Thadou Christian Centenary Committee, December 2008. Printed at Imphal.

14. The author have personally collected the old translated and printed books from various gospel book stores of KBC (Kuki Baptist Convention) and KCC(Kuki Christian Church) located at Imphal, and also visited TBA(Thadou Baptist Association) Headquarter office at Motbung several times and Tribal Research Institute (TRI), Imphal during the past five years or so. Also collected information about the growth and development of literature during informal talks with the church elders and knowledgeable octogenarian of the tribal society on many occasions.

15. Oduyoye, M. A. (2009). Hearing and knowing: Theological reflections on Christianity in Africa. Wipf and Stock Publishers. 